JOURNAL OF PUBLIC HEALTH INOVATION, VOL. 2 NO. 01, DESEMBER 2021

DOI: $10.34305 /$ jphi.v2i1.331
Ciptaan disebarluaskan di bawah

Lisensi Creative Commons Atribusi-

NonKomersial-BerbagiSerupa 4.0

\title{
FAKTOR RISIKO YANG BERHUBUNGAN DENGAN KEJADIAN \\ PREEKLAMPSIA PADA IBU HAMIL TRIMESTER II DAN III \\ DI PUSKESMAS CIBEUREUM KABUPATEN KUNINGAN TAHUN 2019
}

Abik Basyiar, Mamlukah, Dwi Nastiti Iswarawanti, Lely Wahyuniar

STIKes Kuningan

basyiarabik@gmail.com

\begin{abstract}
Abstrak
Angka kematian ibu merupakan indikator rendahnya keadaan ekonomi dan fasilitas pelayanan kesehatan, termasuk pelayanan antenatal dan obstetrik. Salah satu penyebab morbilitas dan mortalitas ibu dan janin adalah preeklamsia dengan angka kejadian sekitar 0,5\% - 38,4\%. Penyebab langsung kematian maternal di dominasi oleh perdarahan, hipertensi dalam kehamilan dan infeksi. Tujuan penelitian ini untuk mengidentifikasi faktor risiko yang berhubungan dengan kejadian preeklampsia pada ibu hamil trimester II dan III di Puskesmas Cibeureum Kabupaten Kuningan. Jenis penelitian ini observasional analitik dengan desain cross sectional (potong lintang). Populasi penelitian ini berjumlah 345 ibu hamil dan pengambilan sampel dengan menggunakan teknik random size sebanyak 223 responden. Analisis data meliputi analisis univariat, analisis bivariat Uji Chi Square dan analisis multivariat menggunakan Regresi Logistik Berganda.

Hasil uji Chi Square menunjukan terdapat hubungan antara usia ibu hamil $(p=0,004)$, jarak kehamilan $(p=0,045)$, riwayat penyakit kronis $(p=0,001)$ dengan kejadian preeklampsia pada ibu hamil. Kemudian tidak terdapat hubungan antara tingkat pendidikan $(p$ $=0,436)$, paritas $(p=0,630)$, obesitas $(p=246)$ dengan kejadian preeklampsia pada ibu hamil. Kesimpulannya, terdapat hubungan antara usia ibu hamil, jarak kehamilan dan Riwayat penyakit kronis dengan kejadian preeklampsia pada ibu hamil. Namun tidak terdapat hubungan antara tingkat Pendidikan, paritas dan obesitas dengan kejadian preeklampsia pada ibu hamil Trimester II dan III di Puskesmas Cibeureum Kabupaten Kuningan Tahun 2019. Dengan begitu, diperlukannya penyuluhan tentang preeklampsia dan pentingnya kontrol kehamilan, membuat penjadwalan penyuluhan mengenai preeklampsia pada kehamilan,
\end{abstract}


JOURNAL OF PUBLIC HEALTH INOVATION, VOL. 2 NO. 01, DESEMBER 2021

DOI: $10.34305 /$ jphi.v2i1.331
Ciptaan disebarluaskan di bawah

Lisensi Creative Commons Atribusi-

NonKomersial-BerbagiSerupa 4.0

memberikan saran format pencatatan untuk data ibu hamil di puskesmas, dan pengadaan poster mengenai preeklampsia di Puskesmas dan Posyandu.

Kata Kunci : Usia, Jarak Kehamilan, Pendidikan, Paritas, Obesitas, Riwayat Penyakit, Preeklamsia

\section{Pendahuluan}

Angka kematian ibu (mortalitas maternal) merupakan indikator yang mencerminkan risiko yang dihadapi ibu sewaktu hamil dan melahirkan. Tingginya kematian ibu menunjukkan rendahnya keadaan ekonomi dan fasilitas pelayanan kesehatan, termasuk pelayanan antenatal dan obstetrik. Penyebab mortalitas maternal diantaranya terbatasnya akses ke pelayanan kesehatan maternal yang berkualitas, terutama pelayanan kedaruratan tepat waktu karena keterlambatan mengenal tanda bahaya dan pengambilan keputusan, keterlambatan mencapai fasilitas kesehatan dan mendapatkan pelayanan di layanan kesehatan (Kementerian kesehatan Republik Indonesia, 2012).

Angka Kematian Ibu (AKI) didefinisikan sebagai angka kematian ibu per 100.000 kelahiran hidup. Berdasarkan hasil SDKI tahun 2007 dan 2012, AKI Nasional menunjukan adanya kenaikan yang sangat besar, yaitu dari 228/100.000 kelahiran hidup menjadi 359/100.000 kelahiran hidup. Data Kementrian Kesehatan RI tahun 2017, jumlah angka kematian ibu (AKI) di Indonesia masih tergolong sangat tinggi diantara negaranegara ASEAN lainnya, yaitu 305/100.000 kelahiran hidup dan masih konstan sampai tahun 2019 (Agustina, 2019). Angka ini masih sangat jauh dari target Sustainable Development Goals (SDG's) yang menargetkan AKI di angka 70/100.000 kelahiran hidup pada tahun 2030.

Angka Kematian Ibu di Jawa Barat pada tahun 2016 sebesar 84,78 per 100.000 kelahiran hidup. Angka ini terus menurun pada tahun 2017 dan 2018 yaitu 76,03 per 100.000 kelahiran hidup dan 24,1 per 100.000 kelahiran hidup (Dinas Kesehatan Jawa Barat, 2020).

Angka kematian ibu masih menjadi masalah di Kabupaten Kuningan karena melebihi angka Jawa Barat. Kuningan menempati peringkat keenam angka kematian ibu tertinggi di Jawa Barat dengan angka 130,7 per 100.000 kelahiran hidup. Angka ini meningkat menjadi sebesar 
JOURNAL OF PUBLIC HEALTH INOVATION, VOL. 2 No. 01, DESEMBER 2021

DOI: $\underline{10.34305 / \text { jphi.v2i1.331 }}$

167,1/100.000 kelahiran hidup pada tahun 2017 dan menurun Kembali pada tahun 2018 menjadi sebesar 122,9/100000 kelahiran hidup (Dinas Kesehatan Kabupaten Kuningan, 2020).

Salah satu penyebab morbiditas dan mortalitas ibu dan janin adalah preeklampsia, dengan angka kejadian berkisar antara 0,5\%- 38,4\%. Di negara maju angka kejadian preeklampsia berkisar 6-7\% dan eklampsia 0,1-0,7\%. Menurut Kementrian Kesehatan Republik Indonesia tahun 2016, penyebab langsung kematian maternal di Indonesia terkait kehamilan dan persalinan terutama masih didominasi oleh tiga penyebab utama yakni perdarahan sebesar 30,3\%, hipertensi dalam kehamilan sebesar 27,1\%, dan infeksi sebesar 7,3\%.

WHO memperkirakan kasus preeklampsia tujuh kali lebih tinggi di negara berkembang daripada di negara maju. Prevalensi preeklampsia di negara maju adalah $1,3 \%$ - 6\%, sedangkan di negara berkembang adalah 1,8\% - 18\%. Insiden kejadian preeklampsia di Indonesia sendiri adalah 128.273 per tahun atau sekitar 5,3\% dari seluruh kehamilan (Kemenkes, 2017).

Terdapat banyak faktor yang mempengaruhi kejadian preeklampsia diantaranya adalah usia ibu kurang dari 20 tahun atau lebih dari 35 tahun, primipara, interval persalinan $<2$ tahun, disamping penyakit vaskuler dan ginjal serta Diabetes Mellitus. Sekitar 65\% ibu mempunyai satu atau lebih 4 kondisi terlalu yakni terlalu muda, terlalu tua, terlalu sering, dan terlalu banyak (Prawirohardjo, 2011) Pada usia $\geq$ 30-35 tahun akan terjadi perubahan pada jaringan dan alat reproduksi dan jalan lahir tidak lentur lagi. Pada usia ini juga cenderung didapatkan penyakit lain di dalam tubuh, contohnya hipertensi(Tanto et al., 2014).

Faktor lain yang berpengaruh terhadap kejadian preeklampsia adalah karakteristik ibu, riwayat kehamilan, berat badan, riwayat penyakit kronis, pengetahuan, dan riwayat kontrasepsi (Setyawati et al., 2018). Riwayat preeklampsia, keturunan serta hipertensi juga dapat mempengaruhi kejadian preeklampsia (Fatkhiyah et al., 2018); (Fatmawati et al., 2017); (Sutrimah et al., 2015). Ibu hamil yang mendapat kunjungan ANC $<4$ kali berisiko untuk mengalami preeklampsia dibandingkan ibu dengan kunjungan $\mathrm{ANC} \geq 4$ kali (Isworo et al., 2012).

Data ibu hamil dengan preeklampsia di Puskesmas Cibeureum terus meningkat. Pada tahun 2017 berjumlah 9 kasus dan meningkat di tahun setelahnya yaitu 41 kasus dan sedikit menurun di tahun 2019 yaitu sebesar 39 kasus. Peningkatan yang 
JOURNAL OF PUBLIC HEALTH INOVATION, VOL. 2 No. 01, DESEMBER 2021

DOI: $10.34305 /$ jphi.v2i1.331
Ciptaan disebarluaskan di bawah Lisensi Creative Commons AtribusiNonKomersial-BerbagiSerupa 4.0 Internasional. sangat signifikan di tahun 2018 menyebabkan Puskesmas Cibeureum menempati peringkat ketiga kasus preeklampsia tertinggi di Kabupaten Kuningan setelah Puskesmas Garawangi (41 kasus) dan Maleber (43 kasus).

Situasi dan kondisi tersebut membuat peneliti tertarik untuk mengkaji faktor risiko yang berhubungan dengan kejadian preeklampsia pada ibu hamil trimester II dan III di Puskesmas Cibeureum Kabupaten Kuningan tahun 2019.

\section{Metode}

Jenis penelitian ini observasional analitik dengan desain cross sectional (potong lintang). Populasi penelitian ini berjumlah 345 ibu hamil dan pengambilan sampel dengan menggunakan teknik random size sebanyak 223 responden. Analisis data meliputi analisis univariat, analisis bivariat Uji Chi Square dan analisis multivariat menggunakan Regresi Logistik Berganda.

Variabel independen dalam penelitian ini yaitu usia, tingkat Pendidikan, jarak kehamilan, paritas, riwayat penyakit kronik dan obesitas. Sedangkan variabel dependen dalam penelitian ini adalah preeklampsia pada ibu hamil trimester II dan III. Adapun populasi dalam penelitian ini adalah semua ibu hamil trimester II dan III di puskesmas Cibeureum dalam kurun waktu Januari-Desember 2019. Total populasi sebanyak 345 ibu hamil. dan pengambilan sampel penelitian dengan menggunakan teknik disproportionate stratified random sampling didapatkan hasil bahwa sampel penelitian sebanyak 223 responden.

Sumber data yang digunakan dalam penelitian ini adalah data sekunder. Data sekunder yang digunakan dalam penelitian ini adalah karakteristik, riwayat kehamilan, dan riwayat kesehatan ibu hamil yang ada di Puskesmas Cibeureum dalam kurun waktu Januari-Desember 2019. Analisis data dalam penelitian ini meliputi analisis univariat, analisis bivariat dengan menggunakan Uji Chi Square dan analisis multivariat dengan menggunakan regresi logistik berganda.

\section{Hasil}

Berdasarkan Tabel 1, gambaran variabel bebas yang diteliti dalam penelitian ini adalah Ibu hamil yang mengalami preeklampsia sebesar $10,3 \%$ dan memiliki jarak dengan kehamilan sebelumnya paling banyak pada rentang 5-10 tahun. hanya ada 2 orang $(0,9 \%)$ yang merupakan kehamilan 
JOURNAL OF PUBLIC HEALTH INOVATION, VOL. 2 No. 01, DESEMBER 2021

DOI: $10.34305 /$ jphi.v2i1.331

pertama (nullipara), sedangkan sisanya 99,1\% merupakan kehamilan yang kedua dan seterusnya (multipara).

Berdasarkan perhitungan indeks massa tubuh sebelum kehamilan, terdapat 82 orang $(36,8 \%)$ ibu hamil yang obesitas
Ciptaan disebarluaskan di bawah Lisensi Creative Commons AtribusiNonKomersial-BerbagiSerupa 4.0 Internasional

atau memiliki IMT $>27 \mathrm{~kg} / \mathrm{m} 2$. Dan hasil penelusuran riwayat penyakit kronik yang diderita, ada 21 orang $(9,4 \%)$ dengan riwayat penyakit kronik diantaranya hipertensi, preeklampsia dan epilepsi.

Tabel 1. Analisis Univariat

\begin{tabular}{|c|c|c|}
\hline Variabel & Jumlah & Persentase \\
\hline \multicolumn{3}{|l|}{ Usia Responden } \\
\hline - $\quad$ Risiko Tinggi $(<20$ Atau $>35$ Tahun) & 53 & 23,8 \\
\hline - $\quad$ Normal (Antara 20-35 Tahun) & 170 & 76,2 \\
\hline \multicolumn{3}{|l|}{ Tingkat Pendidikan } \\
\hline$-\quad \mathrm{SD}$ & 60 & 26,9 \\
\hline - $\quad$ SMP & 99 & 44,4 \\
\hline - $\quad$ SMA & 53 & 23,8 \\
\hline - $\quad$ PT & 11 & $\mathrm{P} 4,9$ \\
\hline \multicolumn{3}{|l|}{ Preeklampsia } \\
\hline$-\quad \mathrm{Ya}$ & 23 & 10,3 \\
\hline - $\quad$ Tidak & 200 & 89,7 \\
\hline \multicolumn{3}{|l|}{ Jarak Kehamilan } \\
\hline$-\quad<5$ Tahun & 59 & 26,5 \\
\hline - 5-10 Tahun & 148 & 66,4 \\
\hline$-\quad>10$ Tahun & 16 & 7,2 \\
\hline \multicolumn{3}{|l|}{ Paritas } \\
\hline - $\quad$ Nullipara & 2 & 0,9 \\
\hline - $\quad$ Multipara & 221 & 99,1 \\
\hline \multicolumn{3}{|l|}{ Obesitas } \\
\hline - Obesitas & 82 & 36,8 \\
\hline - $\quad$ Tidak & 141 & 63,2 \\
\hline \multicolumn{3}{|l|}{ Riwayat Penyakit Kronis } \\
\hline$-\quad \mathrm{Ya}$ & 21 & 9,4 \\
\hline - $\quad$ Tidak & 202 & 90,6 \\
\hline TOTAL & 223 & 100 \\
\hline
\end{tabular}

(Sumber : Penelitian Tahun 2020) 
JOURNAL OF PUBLIC HEALTH INOVATION, VOL. 2 NO. 01, DESEMBER 2021

DOI: $\underline{10.34305 / \text { jphi.v2i1.331 }}$
Ciptaan disebarluaskan di bawah

Tabel 2. Analisis Bivariat Pengaruh Faktor-Faktor Independen Terhadap Kejadian Preeklampsia

\begin{tabular}{|c|c|c|c|c|}
\hline Variabel & Preeklampsia & $\begin{array}{c}\text { Tidak } \\
\text { Preeklampsia }\end{array}$ & Nilai P & OR \\
\hline \begin{tabular}{ll}
\multicolumn{2}{c}{ Usia Responden } \\
$-\quad$ & Risiko Tinggi \\
- & Normal
\end{tabular} & $\begin{array}{l}11(47,8) \\
12(52,2)\end{array}$ & $\begin{array}{c}42(21) \\
158(79)\end{array}$ & 0,004 & 2,61 \\
\hline $\begin{array}{l}\text { Tingkat Pendidikan } \\
-\quad \begin{array}{l}\text { Rendah-Menengah } \\
\text { SMP) }\end{array} \\
-\quad \text { Menengah-Tinggi } \\
\text { PT) }\end{array}$ & $\begin{array}{l}18(78,3) \\
5(21,7)\end{array}$ & $\begin{array}{l}141(70,5) \\
59(29,5)\end{array}$ & 0,436 & 1,64 \\
\hline $\begin{array}{l}\text { Jarak Kehamilan } \\
-\quad<10 \text { Tahun } \\
-\quad>10 \text { Tahun }\end{array}$ & $\begin{array}{l}19(82,6) \\
4(17,4)\end{array}$ & $\begin{array}{c}188(94) \\
12(6)\end{array}$ & 0,045 & 0,382 \\
\hline \begin{tabular}{lr}
\multicolumn{2}{l}{ Paritas } \\
$-\quad$ Nullipara \\
$-\quad$ Multipara
\end{tabular} & $\begin{array}{c}0(0) \\
23(100)\end{array}$ & $\begin{array}{c}2(1) \\
198(99)\end{array}$ & 0,630 & 0,001 \\
\hline \begin{tabular}{ll}
\multicolumn{2}{l}{ Obesitas } \\
$-\quad$ Obesitas \\
$-\quad$ Tidak
\end{tabular} & $\begin{array}{l}11(47,8) \\
12(52,2)\end{array}$ & $\begin{array}{c}71(35,5) \\
129(64,5)\end{array}$ & 0,246 & 1,26 \\
\hline \begin{tabular}{l}
\multicolumn{2}{c}{ Riwayat Penyakit Kronis } \\
$-\quad$ Ya \\
$-\quad$ Tidak
\end{tabular} & $\begin{array}{l}10(43,5) \\
13(56,5)\end{array}$ & $\begin{array}{c}11(5,5) \\
189(94,5)\end{array}$ & 0,001 & 12,61 \\
\hline
\end{tabular}

(Sumber : Penelitian tahun 2020)

Hasil analisis menunjukkan ada dua variabel yang berpengaruh secara signifikan terhadap kejadian preeklampsia yaitu usia ibu hamil, jarak kehamilan dan riwayat penyakit kronis dengan nilai $\mathrm{p}$ sebesar 0,$004 ; 0,045$ dan 0,001. Ibu hamil pada kelompok risiko tinggi memiliki peluang untuk menderita preeklampsia sebesar 2,61 kali dibandingkan ibu hamil dengan usia 20-35 tahun.

Ibu hamil dengan jarak kehamilan kurang dari 10 tahun memiliki peluang sebesar 3 kali untuk menderita preeklampsia jika dibandingkan ibu hamil dengan jarak lebih dari 10 tahun. Ibu hamil yang memiliki riwayat penyakit kronis memiliki peluang 12,6 kali untuk menderita preeklampsia dibandingkan ibu hamil tanpa penyakit kronis sebelumnya. 
JOURNAL OF PUBLIC HEALTH INOVATION, VOL. 2 No. 01, DESEMBER 2021

DOI: $10.34305 /$ jphi.v2i1.331
Ciptaan disebarluaskan di bawah

Lisensi Creative Commons Atribusi-

NonKomersial-BerbagiSerupa 4.0

Tabel 3. Analisis Multivariat

\begin{tabular}{lccc}
\hline \multicolumn{1}{c}{ Variabel } & $\begin{array}{c}\text { OR sebelum diagnosis } \\
\text { penyakit dikeluarkan }\end{array}$ & $\begin{array}{c}\text { OR sesudah diagnosis } \\
\text { penyakit dikeluarkan }\end{array}$ & Perubahan OR (\%) \\
\hline Usia & 2,762 & 2,724 & 3,8 \\
jarak & 0,374 & 0,374 & 0 \\
peny. kronis & 12,12 & 12,778 & 5,43 \\
\hline
\end{tabular}

(Sumber : Penelitian Tahun 2021)

Karena tidak ada perubahan > $10 \%$, maka variabel obesitas tetep dikeluarkan dalam model. Kejadian preeklampsia di wilayah kerja Puskesmas Cibeureum dipengaruhi oleh Riwayat penyakit kronis dengan dikontrol oleh variabel usia dan jarak kehamilan dengan persamaan sebagai berikut:

$\mathrm{Z}=\operatorname{logit}($ preeklampsia $=1)=-$ $3,000+1,002$ usia $+2,548$ riwayat penyakit kronis - 0,984 jarak kehamilan.

\section{Pembahasan}

1. Pengaruh Usia terhadap Kejadian Preeklampsia.

Hasil penelitian ibu hamil di Puskesmas Cibeureum dalam kurun waktu Januari - Desember 2019 menunjukkan bahwa usia resiko tinggi kurang dari 20 tahun dan lebih dari 35 tahun berpengaruh terhadap kejadian preeklampsia pada ibu hamil di
Puskesmas Cibeureum kecamatan Cibeureum Kabupaten kuningan dan memiliki risiko 2,61 kali dibandingkan ibu hamil dengan usia 20 35 tahun.dengan nilai p 0,004 artinya Ho ditolak dan ada hubungan antara variabel bebas dengan variabel terikat.

Penelitian ini sejalan dengan hasil penelitian yang menyatakan bahwa usia ibu hamil ada hubunganya dengan kejadian preeklamsia (Fatkhiyah et al., 2018). Selain, itu penelitian lain pun menyatakan bahwa terdapat hubungan antara usia ibu hamil kejadian preeklamsia (Sari et al., 2019).

Sedangkan penelitian ini tidak sejalan lain yang menyatakan bahwa tidak ada hubungan yang signifikan faktor risiko umur dengan kejadian preeklampsia dengan nilai $p=0,768$ dan $\mathrm{OR}=1,190$ (Sutrimah et al., 2015).

2. Pengaruh Tingkat Pendidikan terhadap Kejadian Preeklampsia

Dari hasil analisis tingkat pendidikan rendah sampai menengah (SD-SMP) angka 
JOURNAL OF PUBLIC HEALTH INOVATION, VOL. 2 NO. 01, DESEMBER 2021

DOI: $\underline{10.34305 / j p h i . v 2 i 1.331}$
Ciptaan disebarluaskan di bawah

Lisensi Creative Commons Atribusi-

NonKomersial-BerbagiSerupa 4.0 kejadian preeklamsia di puskesmas Cibeureum kurun waktu JanuariDesember 2021 adalah $18 \mathrm{ibu}$ hamil (78,3\%), sedangkan lulusan menengahtinggi (SMA-PT) ada 5 ibu hamil $(21,7 \%)$ nilai p 0,436 maka Ho gagal ditolak berarti tidak ada hubungan antara variabel bebas dengan variabel terikat.

Penelitian ini tidak sejalan dengan penelitian yang dilakukan oleh (Sari et al., 2019) dimana preeklampsia berhubungan secara tidak langsung dengan Pendidikan.

3. Pengaruh Jarak Kehamilan terhadap Kejadian Preeklampsia.

Pengaruh jarak kehamilan terhadap kejadian preeklamsia memiliki nilai $\mathrm{p}$ 0,045 artinya ada hubungan antara variabel bebas dengan variabel terikat. Hasil penelitian ibu hamil di Puskesmas Cibeureum dalam kurun waktu Januari - Desember 2019 menunjukkan bahwa Risiko jarak kehamilan berhubungan dengan preeklamsia akan meningkat lebih dari tiga kali lipat.

Hal ini sesuai dengan penelitian yang menunjukan bahwa ada hubungan antara jarak kehamilan dengan kejadian preeklamsia pada ibu hamil di RS Aura Syifa Kabupaten Kediri Tahun 2015 (Wulandari, 2015).

4. Pengaruh Paritas terhadap Kejadian Preeklampsia

Hasil penelitian di Puskesmas Cibeureum (2020) menunjukkan hasil uji statistik bivariat dengan uji chi square diperoleh nilai OR 0,001 dengan nilai $p$ 0,630. Dimana nilai $\mathrm{p}$ lebih besar dari 0,05 artinya Ho gagal ditolak artinya tidak ada hubungan antara variabel bebas dengan variabel terikat.

Penelitian ini sejalan dengan hasil penelitian yang dilakukan oleh (Sari et al., 2019) dan (Sutrimah et al., 2015) yang menunjukan bahwa tidak terdapat hubungan antara paritas dengan kejadian preeklamsia.

Penelitian ini tidak sejalan dengan hasil penelitian yang dilakukan oleh (Fatmawati et al., 2017) karena hasil menunjukkan adanya pengaruh yang signifikan antara paritas dengan kejadian preeklamsia dengan nilai $p=0,000$.

5. Pengaruh Obesitas terhadap Kejadian Preeklampsia

Berdasarkan perhitungan indeks massa tubuh sebelum kehamilan pada penelitian di Puskesmas Cibeureum kurun waktu Januari Desember 2019 , terdapat 82 orang $(36,8 \%)$ 
JOURNAL OF PUBLIC HEALTH INOVATION, VOL. 2 No. 01, DESEMBER 2021

DOI: $10.34305 /$ jphi.v2i1.331

ibu hamil yang obesitas atau memiliki IMT $>27 \mathrm{~kg} / \mathrm{m} 2$. Dengan nilai $\mathrm{p}=$ 0,246 artinya Ho di gagal di tolak dan menunjukan tidak ada hubungan antara variabel bebas dengan variabel terikat.

Penelitian ini tidak sejalan dengan penelitian yang dilakukan oleh (Setyawati et al., 2018) yang menjelaskan bahwa terdapat hubungan yang signifikan antara berat badan dengan kejadian preeklamsi dengan nilai $p=0,000$.

6. Pengaruh Riwayat Penyakit Kronis terhadap Kejadian Preeklampsia

Hipertensi merupakan salah satu penyakit kronik yang ada dalam kehamilan. Penelitian di Puskesmas Cibeureum (2020) dengan menggunakan uji Chi square didapatkan nilai OR 12,6 artinya seorang ibu hamil dengan riwayat hipertensi mempunyai peluang 12,6 kali terjadi preeklampsia, dibandingkan ibu hamil tanpa penyakit kronis sebelumnya, dimana nilainya sangat signifikan dengan nilai $\mathrm{p}=0,001$ artinya Ho ditolak dan ada hubungan antara variabel bebas dengan variabel terikat.

Penelitian ini sejalan dengan hasil penelitian yang menjelaskan bahwa terdapat pengaruh yang signifikan antara Riwayat penyakit kronis terhadap kejadian preeklamsia (Fatkhiyah et al., 2018); (Fatmawati et al., 2017); (Sari et al., 2019); (Setyawati et al., 2018).

\section{Kesimpulan}

Berdasarkan hasil analisis dalam penelitian ini dapat disimpulkan bahwa terdapat tiga variabel yang berpengaruh secara signifikan terhadap kejadian preeklampsia yaitu usia ibu hamil, jarak kehamilan dan riwayat penyakit kronis dengan nilai p sebesar 0,004; 0,045 dan 0,001. Dengan adanya hasil analisa ini, usia kehamilan, jarak kehamilan dan riwayat penyakit kronis sangat berhubungan dengan preeklamsia yang ada di puskesmas Cibeureum dalam jangka waktu Januari Desember 2019.

\section{Saran}

Upaya yang dapat dilakukan oleh Puskesmas dan Dinas Kesehatan untuk mencegah kejadian preeklampsia yakni dengan melakukan penyuluhan tentang preeklampsia dan pentingnya kontrol kehamilan, membuat penjadwalan penyuluhan mengenai preeklampsia pada kehamilan, memberikan saran format pencatatan untuk data ibu hamil di 
JOURNAL OF PUBLIC HEALTH INOVATION, VOL. 2 No. 01, DESEMBER 2021

DOI: $10.34305 /$ jphi.v2i1.331
Ciptaan disebarluaskan di bawah Lisensi Creative Commons AtribusiNonKomersial-BerbagiSerupa 4.0 Internasional puskesmas, dan pengadaan poster mengenai preeklampsia di Puskesmas dan Posyandu.

Bagi ibu hamil diharapkan dapat meningkatkan pengetahuan tentang preeklampsia sehingga dapat melakukan tindakan pencegahan agar tidak mengalami kejadian preeklamsia ketika hamil.

\section{Daftar Pustaka}

Dinas Kesehatan Jawa Barat. (2020). Profil Kesehatan Jawa Barat Tahun 2019. In Dinas Kesehatan Jawa Barat.

Dinas Kesehatan Kabupaten Kuningan. (2020). Profil Kesehatan Kuningan. Dinas Kesehatan Kabupaten Kuningan Jawa Barat.

Fatkhiyah, N., Kodijah, K., \& Masturoh, M. (2018). Determinan Maternal Kejadian Preeklampsia: Studi Kasus Di Kabupaten Tegal, Jawa Tengah. Jurnal Keperawatan Soedirman, $\quad 11(1), \quad 53$. Https://Doi.Org/10.20884/1.Jks.20 16.11.1.642

Fatmawati, L., Sulistyono, A., \& Notobroto, H. B. (2017). Influence Of Maternal Health Status To Degree Of Preeclampsia/Eclampsia In Gresik. Buletin Penelitian Sistem Kesehatan, 20(2). Https://Doi.Org/10.22435/Hsr.V20 i2.6165.52-58

Isworo, A., Hakimi, M., \& Wibowo, T. A. (2012). Hubungan Antara
Kecemasan Dengan Kejadian Preeklampsia Di Kabupaten Banyumas Jawa Tengah. Berita Kedokteran Masyarakat, 28(1), 9-19.

Kemenkes, R. I. (2017). Profil Kesehatan Indonesia 2016. Kementerian Kesehatan Republik Indonesia.

Kementerian Kesehatan Republik Indonesia. (2012). Pedoman Pelayanan Antenatal Terpadu. Ditjen Bina Gizi Dan Kia Kemenkes.

Prawirohardjo, S. (2011). Ilmu Kebidanan (Edisi Ke-4). Yayasan Bina Pustaka.

Sari, P. W., Budihastuti, U. R., \& Pamungkasari, E. P. (2019). Path Analysis On The Determinants Of Severe Preeclampsia In Surakarta, Central Java. Journal Of Maternal And Child Health, 4(2), 126-135. Https://Doi.Org/10.26911/Thejmch.2019 .04 .02 .08

Setyawati, A., Widiasih, R., \& Ermiati, E. (2018). Faktor-Faktor Yang Berhubungan Dengan Kejadian Preeklampsia Di Indonesia. Jurnal Perawat Indonesia, 2(1), 32. Https://Doi.Org/10.32584/Jpi.V2i1.38

Sutrimah, S., Mifbakhudin, M., \& Wahyuni, D. (2015). Faktor-Faktor Yang Berhubungan Dengan Kejadian Preeklampsia Pada Ibu Hamil Di Rumah Sakit Roemani Muhammadiyah Semarang. Jurnal Kebidanan, 4(1), 110.

Tanto, C., Liwang, F., Hanifati, S., \& Pradipta, E. A. (2014). Kapita Selekta Kedokteran. Jakarta: Media Aesculapius, 329-330. 
JOURNAL OF PUBLIC HEALTH INOVATION, VOL. 2 No. 01, DESEMBER 2021

DOI: $\underline{10.34305 / \text { jphi.v2i1.331 }}$

Wulandari, S. (2015). Hubungan Antara Jarak Kehamilan Dan Status Gizi Dengan Kejadian Preeklamsi Pada Ibu Hamil Di Rs Aura Syifa Kabupaten Kediri Tahun 2015. File. Fakultas Ilmu Kesehatan Universitas Kediri.
Ciptaan disebarluaskan di bawah Lisensi Creative Commons AtribusiNonKomersial-BerbagiSerupa 4.0 Internasional. 